rosearch programmes were to be assessod by the now Research Council, and it was tho Government's intention, in the light of tho advico it received from the Research Council, to do what it could in oceanographie research. This was not a field in which inßdoquate resources need. limit Britain's participation.

\section{Business Schools}

IN reply to quostions in the House of Commons on Juno 24 rogarding progress in establishing the new business schools, the Secretary of State for Education and Science, Mr. A. Crosland, stated that both schools had leasod temporary premises which were being adapted and equipped, and staff were being recruited. 'The first fulltime course at Manchester would begin next September. In London it was hoped to hold some part-time courses this autumn and full-time courses would start next Fubruary. 'The London. School had appointed its director. Ho was satisfied that liaison between. the Schools and the Ministry of Technology and the (xovornmont genorally would be close and sufficiont.

\section{Liberal Studies in a Technological Education}

UNDER the title Symposium on Liberal Studies the British Association for Commercial and Industrial Education has collected a series of articles issued in the Association's Journal over the past 18 months (Pp. 40. London: British Association for Commercial and Industrial Education, 1964. 10s.). The president of the Association, Sir Willis Jackson, contributes a foreword, and there is an introduction by Sir Eric Ashby, in which he states his reason for regarding the liberal studies programmo in the colleges of advanced technology as one of the initially important educational experiments of this century. There is also a select bibliography compiled by Mr. D. R. O. Thomas, characterized by breadth and vision, though, as always, there is room for two opinions as to the merits of including some particular books as agsinst altcrnatives. In the first of the six articles, Prof. T. Lupton argues the claims of industrial administration to be a liberal undergraduate study. In the sccond, $H$. N. Sheldon describes the aims, content and methods of these studies, which are the responsibility of the general or liberal studies departments in colloges of advanced technology and assesses their value as an integral part of the training of undergraduate technologists. In the third, "Teaching Tochnology--2 Libcral Approach", Mr. J. P. Moore describes the present aims and methods in teaching metallurgy at Bitterne College of Technology; Mr. D. J. Isaac's "Concepts and Mothods in Science Teaching" examines the attitudes and assumptions of students and teachers at Brunol College and describes the action taken to remody an unsatisfactory situation. Under the title "Humanities and Technology—a New Discipline", Mr. A. M. Duncan discusses the imporative need for a single systom rather than two separato aspocts of tho same culture. Finally, Sir Leslie Rowan in an article, "Liberal Studies in 'Technology", examines the need for a change in attitude to training for management.

\section{British Admiral: A Super Oil Tanker}

ON March 17, 1965, British Admiral, the first tanker of 100,000 tons deadweight to be built in Europe, was christened and launched by H.M. The Queen at Barrow-inFurness, at the yard of Vickers-Armstrongs (Shipbuilders), Ltd. 'This was a great occasion, but there was also another soon to follow. In April 1965 tho British Petroleum Tanker Company, the shipping subsidiary of the British Potroleum Company, celebrated its jubilee and to mark both events a rceent issue of the BP Magazine, that colourful quarterly, is devoted entirely to sea-going oil-tankers and to tho history of the British Petroleurn Tanker Company in particular (15, Spring 1965. Pp. 32. British Petroleum Co., Ltd., Tundon, E.C.2). "During these 50 yoars, the
British Petroleum Tanker Company has grown from modest beginnings to become the operator of one of the largost privately owned fleets in the world. The ships themselves have grown in size and complexity and the business of tanker operation, whether from the viewpoint of tho man at sca or in the office, has developed to the point where it is at once both an art and a science." The articles in this publication, written by exports, aided by a series of excellent illustrations and diagrams, not only record the achievements of the British Petroleum Tanker Company over the years, but they are also a valuable insight into the evolution of oil-tankers in general; as such, they make commendably instructive reading for all interested in this vital aspect of intornational oil operations. The contributions are: "From Whaling Brig to Super Tanker", by M. Clérnans and R. Ilian; "Those Who Go to Sea" (anon.); "A Tanker is Built", by Commander E. H. W. Platt; "Spccial Services", by Captain G. A. B. King. There is a special supplement in photogravure illustrating the actual launehing of British Admiral and inside this folder are representations of some of the original plans used for its construction. From these and some explanatory notes it is learnt that, compared with the Queen Elizabeth (overall length 1,031 ft.), British Admiral is $917.5 \mathrm{ft}$.; breadth is $118 \mathrm{ft}$., and $128 \mathrm{ft}$., respectively; the tanker's depth to upper deck is $66 \mathrm{ft}$; her service speed, loaded, about 15.5 knots. Other details of ongines and general layout of this 'big ship', also of the commodore and chief enginoer, whose responsibility she will be, completo what is a most worthy tribute to all concerned with her commission.

\section{The Quekett Microscopical Club}

THIs year the Quekett Microscopical Club celebrates the centenary of its foundation on July 7,1865 . The title of the Club commemorates the name of John Thomas Quekett, professor of histology and conservator of the Hunterian Museum at the Royal College of Surgeons of England. A prominent microscopist in his day, a founder momber of the Microscopical Society of London (now the Royal Microscopical Society), Fellow of the Royal Society and of the Linnean Society of London, and author of the Practical Treatise on the Microscope, Quekett died in 1861 at the early age of forty-six, greatly respected by all who knew him. 'Thore were at the time several suggestions current for commemorating his name in some permanent way. As events have proved, no more appropriate memorial to him could have come of this desire than the association of his name with this Club, which has met twice-monthly for the past hundred years, and to-day enjoys a worldwide membership. Appropriately, the Club's president in this centenary year is Prof. George J. Cunningham, who occupies the chair of pathology at the Royal College of Surgeons. The principal event to mark this occasion will be a two-day celebration meeting and exhibition of micro. scopy, which will bo open to visitors. This will be held in the Centrol Hall, Westminster, S.W.1, during October 8-9. The theme of the meeting will bo two-fold : first, to illustrate the founding and history of the Club; and sccondly, to present a survey of present-day microscopy and microscopical equipment in science and industry, in addition to its recreational aspects. Demonstrations of films, slides and microprojection will also be staged throughout the two days.

\section{The Manchester Museum}

THE report for the year ending July 31 , 1964, recalls that for several ytars tho policy of the Manchester Museum has been to concentrate on the more attractive display of its oxtensive collections (Pp. 20. Manchestor: The Manchester Museum, The University, 1965). To this end, a now Japanose gallery has been arranged and the Cannon Aquarium opened to the public. The lattor was romoved from the Zoology Department of the University and 